\title{
Etika Bisnis E-Commerce Shopee Berdasarkan Maqashid Syariah Dalam Mewujudkan Keberlangsungan Bisnis
}

\author{
Ruslang $^{1}$, Muslimin Kara ${ }^{2}$, Abdul Wahab ${ }^{3}$ \\ ${ }^{1}$ Pascasarjana, UIN Alauddin Makassar \\ ${ }^{2,3}$ Fakultas Eonomi dan Bisnis Islam, UIN Alauddin Makassar \\ *Email Korespondensi: ruslanalfurqan86@gmail.com
}

\begin{abstract}
This study discusses Shopee's e-commerce business ethics based on maqashid sharia in realizing business continuity. Business ethics are the foundation of contemporary business because buyers and sellers do not meet in person. Maintaining the trust of two parties, an absolute requirement for online trading, it is important to apply business ethics based on maqashid sharia. The implication of this is the building of mutual trust between buyers, sellers and Shopee online stores. This study aims to reveal the implications of implementing business ethics based on maqashid sharia at Shopee. This research method uses descriptive qualitative research with field research. In the research results, Shopee applies business ethics based on maqashid sharia so that buyers are increasing and sellers are more loyal and Shopee's business continuity is getting stronger.
\end{abstract}

Keywords: Business Ethics, E-Commerce, Shopee, Maqashid Shariah

Saran sitasi: Ruslang., Kara, M., \& Wahab, A. (2020). Etika Bisnis E-Commerce Shopee Berdasarkan Maqashid Syariah Dalam Mewujudkan Keberlangsungan Bisnis. Jurnal Ilmiah Ekonomi Islam, 6(03), 665-674. doi: http://dx.doi.org/10.29040/jiei.v6i3.1412

DOI: http://dx.doi.org/10.29040/jiei.v6i3.1412

\section{PENDAHULUAN}

Etika dalam bisnis (Aziz, 2013) adalah sesuatu yang menjadi bagian penting pada bisnis digital. Bisnis maupun etika bukanlah dua hal yang bertentangan, karena bisnis sebagai simbol perwujudan urusan keduniaan juga merupakan tabungan ukhrawi. Artinya, jika orientasi bisnis dan upaya tabungan akhirat diniatkan untuk kepatuhan kepada Allah, maka bisnis dengan sendirinya harus sejalan dengan konsep-konsep akhlak yang berdasarkan keyakinan kepada hari akhirat. Bahkan dalam Islam, definisi bisnis itu sendiri tidak dibatasi urusan keduniaan semata, tetapi mencakup juga keseluruhan pada kegiatan seseorang di dunia yang "dibisniskan" (diniatkan sebagai ibadah) untuk mencapai falah dan pahala akhirat.

Muhammad Saw (Saifullah, 2011) merupakan seorang pebisnis yang menjadi model terbaik dalam praktik perniagaan di zaman Jahiliyah. Keberhasilan Nabi Muhammad dalam melakukan bisnis sangat dipengaruhi oleh pribadi dan attitude beliau, dimana Muhammad Saw selalu menerapkan nilai-nilai etika dalam berbisnis. Etika bisnis Muhammad dalam kebiasaannya selalu melakukan praktek bisnis yang baik antara lain: kejujuran, amanah, tepat menimbang, menjauhi praktik gharar, tidak melakukan penimbunan barang (ikhtikar), tidak melakukan penipuan (al ghabn) dan kecurangan (tadlis) dan saling menguntungkan.

Sesuai ajaran Islam (Sudiarti, 2018) interaksi yang dilakukan oleh manusia dalam kehidupan seharihari, telah diatur dalam sistem muamalah. Pada hakikatnya sistem bermuamalah didasarkan pada kebolehan/mubah. Sistem mubah ini, memberikan konsekuensi yang jelas demi tercapainya tujuan kehidupan manusia yang dikenal dengan istilah falah, yaitu kesejahteraan dunia dan akhirat. Kesejahteraan dalam prinsip ekonomi Islam (Soediro \& Meutia, 2018) haruslah mampu mewujudkan maksud-maksud syariah, yang dikenal dengan maqashid syariah, yang mencakup pemeliharaan terhadap lima unsur kehidupan, yakni penjagaan terhadap agama, jiwa, akal, keturunan dan harta. Tercapainya lima unsur tersebut akan membawa implikasi yang disebut konsep maslahah. 


\section{Jurnal Ilmiah Ekonomi Islam, 6(03), 2020, 666}

Penggunaan teknologi dan informasi dalam bidang perdagangan telah berkembang dengan sangat pesat melalui bentuk teknologi digitalisasi, mobilitas modal dan liberalisasi informasi. Perdagangan di zaman teknologi internet lebih dikenal dengan istilah e-commerce (electronic commerce) akhir-akhir ini telah marak dengan kemunculan ribuan pedagang yang memasarkan barang jualannya lewat website. Kebutuhan mendasar dalam merancang perdagangan elektronik (e-commerce) adalah mempromosikan informasi keunikan barang dan memperluas area pangsa pasar dengan sasaran lebih luas untuk mencapai keuntungan dan daya saing yang lebih kompetitif dan bersifat global (Chasanah et al., 2018).

E-commerce (Misbahuddin, 2012) merupakan suatu sistem yang dibangun dengan tujuan untuk meningkatkan kemudahan dan efektifitas dalam berdagang dengan memanfaatkan teknologi dan informasi (internet) dalam meningkatkan kualitas barang/jasa dan informasi serta mengurangi beban biaya yang tidak dipenting sehingga harga barang dan informasi tersebut dapat ditekan dengan maksimal tanpa mengurangi kualitas barang tersebut.

Menurut Salwani, di era globalisasi sekarang, pemasaran tidak hanya sebatas tatap muka, tapi pemasaran dengan sistem online melalui internet, atau biasa disebut bisnis E-Commerce. E-Commerce akan melakukannya mampu meningkatkan pemasaran produk dan memperluas pasar baik nasional maupun internasional. E-Commerce memiliki indikator: Pembelian secara online, Komunikasi secara digital, serta pelayanan dan proses pembelian secara daring. Praktik e-commerce akan bisa untuk memperluas jangkauan pemasaran UKM, meningkatkan permintaan, memelihara dan mengembangkan hubungan dengan distributor, pelanggan dan pemasok dengan cepat dan tepat waktu (Farida et al., 2017).

Terwujudnya pemanfaatan dan penggunaan teknologi internet (Dewi Irmawati, 2011) diharapkan bisa memberikan implikasi yang maksimal terhadap dunia perdagangan yang semakin kompetitif. Suatu perusahaan yang mampu berdaya saing dalam catur kompetisi tersebut adalah perusahaan yang mampu mengadaptasi teknologi dan informasi kedalam perusahaannya. Salah satu jenis implementasi teknologi dalam hal meningkatkan persaingan bisnis dan penjualan barang-barang adalah dengan menggunakan electronic commerce (e-commerce) untuk mempromosikan berbagai macam produk atau jasa, baik dalam bentuk fisik maupun digitalisasi.
Shopee (Meidita et al., 2018) merupakan salah satu perusahaan bisnis online (e-commerce) termuda yang sedang berkembang dengan sangat pesat dalam pasar jual beli online. Marketplace berbasis mobile ini secara resmi masuk ke Indonesia pada tahun 2015 di banding pesaingnya lebih dahulu beroperasi. Pada 2018, Shopee telah meraih 1,5 juta transaksi dalam waktu 24 jam hal ini merupakan rekor fantastis bagi marketplace e-commerce terbaru di Indonesia. Semakin banyaknya jumlah pengguna dan pelanggan Shopee saat ini, tidak menutup kemungkinan masih dapat terjadi suatu masalah seperti pelanggan meresa kecewa dengan pelayanan yang telah diberikan, pembeli yang terkena tipu. Dan adanya beberapa pengguna/pembeli yang menerima barang tidak sesuai dengan apa yang dipesan atau barang mengalami kerusakan. Barang tidak sampai ke alamat tujuan. Bahkan pengembalian uang yang tidak di proses oleh seller. Jika hal tersebut dibiarkan akan berdampak negatif pada keberlangsungan bisnis Shopee.

Berdasarakan latar belakang masalah di atas, maka peneliti memberikan batasan terhadap masalah yang dikaji dalam penelitian ini adalah, pertama, bagaimana penerapan etika bisnis e-commerce Shopee berdasarkan maqashid syarih dalam bisnis? Kedua, bagaimana etika bisnis e-commerce Shopee berdasarkan maqashid syariah dapat mewujudkan keberlangsunagn bisnis?

Penelitian ini bertujuan untuk mengungkap penerapan etika bisnis e-commerce Shopee yang didasarkan pada maqashid syariah dalam menjalankan bisnis. Selanjutnya, mengungkap pengaruh penerapan etika bisnis yang didasarkan maqashid syariah dapat meningkatkan dan mewujudkan keberlangsungan bisnis Shopee.

\section{KAJIAN PUSTAKA}

\subsection{Konsep Etika Bisnis}

Istilah etika (Dewantara, 2017) merupakan kata umum yang merujuk pada baik buruknya perilaku manusia. Etika merupakan titik tolak baik dan buruk yang menjadi referensi pengambilan keputusan personal sebelum melakukan serangkaian aktifitas. Etika tidak hanya sebatas larangan-larangan normatif, akan tetapi lebih merupakan puncak keseluruhan kemampuan operasionalisasi kecerdasan manusia. Karena melibatkan kemampuan operasionalisasi kecerdasan manusia, etika juga disebut dengan sistem filsafat, atau filosofi yang mempertanyakan praksis 


\section{Jurnal Ilmiah Ekonomi Islam, 6(03), 2020, 667}

manusia berkaitan dengan responsibilitas dan kewajibannya.

Menurut Erni Setyaningsih dalam (Anindya, 2017) bahwa etika bisnis Islam, merupakan segala perilaku bisnis (wirausaha) dalam bertransaksi seharusnya tidak sekedar bertujuan mencari keuntungan sebesar-besarnya dan semaksimalnya, akan tetapi juga yang paling urgen adalah mencari keridhaan dan mencapai keberkahan atas rezeki yang diperoleh yang diberikan oleh Allah SWT. Keuntungan bukanlah semata-mata tujuan yang harus selalu diprioritaskan. Dunia bisnis juga harus berfungsi sosial dan harus dijalankan dengan memperhatikan etika-etika yang berlaku di dalam masyarakat.

Menurut Harahap dalam (Sampurno, 2016) etika dalam Islam merupakan buah dari keimanan, keislaman, dan ketaqwaan yang didasarkan pada keyakinan yang kuat pada kebenaran Allah SWT. Islam merupakan sumber nilai dan etika dalam segala aspek kehidupan manusia yang menyeluruh, termasuk dalam wacana bisnis. Bisnis yang Islami harus lahir untuk kepentingan beribadah kepada Allah SWT dengan niatan akan memenuhi aturan Ilahi.

Yusuf Qardhawi mengemukakan dalam (Djakfar, 2007) mengemukakan bahwa bisnis dan etika tidak dapat dipisahkan. Mereka hanya seperti pengetahuan dan etika, politik dan etika, serta air dan etika. Etika adalah daging dan saraf dalam kehidupan Islam karena ajaran Islam didasarkan pada etika prinsip. Umat percaya pada kesatuan hidup dan hidup. Karenanya, kita tidak bisa menerima konsep yang memisahkan kehidupan duniawi dan agama, seperti yang terjadi di Eropa. Dari perspektif Islam, seorang pebisnis tidak hanya mencari keuntungan, tetapi juga berkah dari Allah.

Prinsip-prinsip etika bisnis yang dikenal menurut al-Qur'an (Nawatmi, 2010): pertama, Islam melarang melakukan bisnis yang diproses secara kebatilan. Bisnis harus didasari keridhaan dan transparansi antara kedua belah pihak dan tanpa ada pihak yang merasa dirugikan. Kedua, Bisnis tidak diperbolehkan mengandung intrik ribawi. Ketiga, kegiatan transaksi dalam bisnis juga memiliki fungsi control sosial baik melalui zakat dan sedekah. Keempat, melarang pengurangan hak terhadap suatu benda maupun komoditas yang diperoleh atau diproses dengan alat takaran dan timbangan karena akan merugikan pihak lain serta merupakan bentuk kezaliman. Kelima, menjunjung tinggi nilai-nilai tawazun baik ekonomi maupun sosial, keselamatan dan kebaikan serta tidak menyepakati tindakan kerusakan dan ketidakadilan. Keenam, pelaku bisnis dilarang berbuat aniaya (curang) baik terhadap dirinya sendiri maupun kepada pelanggan bisnis yang lain.

Etika bisnis Islam merupakan akhlak dalam melakukan bisnis sesuai dengan nilai-nilai yang sepakati dalam Islam, sehingga dalam melaksanakan bisnis tersebut tidak perlu ada rasa kekhawatiran, sebab sudah diyakini sebagai sesuatu tindakan dan aturan yang baik dan benar. Nilai etik, moral, susila atau akhlak adalah suatu nilai yang mengontrol dan mendorong manusia menjadi pribadi yang sempurna. Seperti kejujuran, kebenaran, keadilan, kemerdekaan, kebahagiaan dan cinta kasih saying, Ali Hasan dalam (Juliyani, 2016).

Menurut Norvadewi dalam (Tiakoly et al., 2019) pengusaha harus memiliki sikap tanggung jawab terhadap pelanggan, hal ini sangat diperlukan adanya praktek-praktek etika bisnis Islam yang mengatur, mengontrol terhadap segala kegiatan usaha bisnis tersebut agar dalam melakukan praktek bisnis tidak ada unsur-unsur yang merasa dizalimi. Sebagaimana tujuan yang dikehendaki dari pada bisnis Islam itu sendiri yakni, untuk mendapatkan laba (profit), mempertahankan keberlangsungan bisnis, pertumbuhan sosial, dan sikap pertanggung jawaban sosial.

\subsection{Konsep Maqshid Syariah}

Wahbah al-Zuhaili (Fauzi, 2015) mendefinisikan maqashid syari'ah dengan makna-makna dan tujuantujuan yang dijaga oleh syara' dalam segala aspek hukumnya atau sebagian besar dari hukumnya, atau bertujuan akhir dari syariat dan menyimpan rahasiarahasia yang ditetapkan oleh syara' pada segala hukumnya. Menurut Yusuf Qardhawi Salah satu maksud dari syariah (maqashid syariah) adalah terlaksananya keadilan. Keadilan ini dimaksudkan bahwa si konsumen tidak dirampas haknya oleh suatu perusahaan serta keharusan perusahaan memproduksi produk yang menguntungkan bagi konsumen. Sehingga antara perusahaan dan konsumen memiliki ikatan yang bisa saling menguntungkan.

Para ulama terdahulu (Wulandari et al., 2018) seperti Al-Syatibi, menetapkan tangga tingkatan maqashid syariah menjadi tiga bagian yaitu, al maqashid dharuriyat, al maqashid hajiyyat dan al maqashid tahsiniyat. Al maqashid dharuriyat lebih menekankan pada pemeliharaan kebutuhan pokok 
yang darurat bagi manusia. Jika kebutuhan ini tidak dipenuhi dengan baik, maka akan dapat berpengaruh dan mengancam keselamatan dunia dan akhirat. Tingkatan selanjutnya al maqashid hajiyyat adalah merupakan kebutuhan sekunder/penunjang. Apabila tidak terpenuhi maka tidak mengancam keselamatan manusia namun dapat menimbulkan kesulitan hidup. Terakhir ialah al maqashid tahsiniyat yaitu kebutuhan komplementer/pelengkap. Jika tidak dipenuhi tidak mempengaruhi keselamatan dan tidak akan menimbulkan kesulitan bagi manusia. Menurut (Putra, 2015) dalam mengukur dan menimbang keberhasilan suatu entitas dalam melaksanakan skala prioritas kebutuhan dalam pencapaian falah, maka Islam telah menetapkan aturan yang kemudian disebut Maqashid Syariah. Dengan Maqashid syariah maka akan diuraikan parameter kemaslahatan yang hendak diperoleh.

Penjelasan rinci megenai maqashid dharuriyah, Al-Syatibi menjelaskan (Hadi, 2012) bahwa ia memiliki kemaslahatan dan keselamatan pokok yang telah disepakati yang mencakup lima hal, yaitu: Menjaga agama (hifdz ad-din); sebagai alasan diwajibkannya berdakwah ke jalan Allah, bermuamalah dan bertransaksi secara islami, dan berjihad jika ada yang berusaha mememerangi agama ini; Menjaga jiwa (hifdz an-nafs); sebagai alasan diwajibkannya memenuhi kebutuhan pokok manusia untuk melangsungkan hidup (sandang, pangan dan papan) dan menegakkan hukum qishash untuk menjaga kemuliaan darah dan jiwa manusia; Menjaga akal (hifdz al-'aql); sebagai alasan diwajibkannya belajar ilmu sepanjang hayat, diharamkannya mengkonsumsi dan menjual benda yang memabukkan seperti khamar dan narkoba; Menjaga keturunan (hifdz an-nasl); sebagai alasan diwajibkannya menjaga kualitas keturunan, dan diharamkannya perzinahan serta perkawinan yang sedarah; Menjaga harta ( $h i f d z$ al-mal); sebagai alasan diwajibkannya memperoleh harta dengan halal, mengelola dan megembangkan harta atau kekayaan secara baik, sebab dengan investasi kekayaan yang dimiliki akan dapat menjaga empat tujuan syariah yang ada diatasnya. Serta diharamkannya pencurian/perampokan, suap menyuap, korupsi, bertransaksi riba dan merampas hak kekayaan orang lain dengan jalan batil.

\subsection{E-Commerce}

Menutut Siregar dalam (Yulistia, 2017) electronic commerce (e-commerce) adalah proses pembelian, penjualan atau pertukaran produk, jasa dan informasi melalui jaringan komputer. e-commerce merupakan bagian dari e-business, dimana cakupan $e$ business lebih luas, tidak hanya sekedar perniagaan tetapi mencakup juga pengkolaborasian mitra bisnis, pelayanan nasabah, lowongan pekerjaan dll. Selain teknologi jaringan, e-commerce juga memerlukan teknologi basis data atau pangkalan data (database), $e$ surat atau surat elektronik (e-mail), dan bentuk teknologi non komputer yang lain seperti halnya sistem pengiriman barang, dan alat pembayaran $e$ money.

E-commerce means transaction between buyers and sellers on Electronic platform explained in other words as online. E-Commerce is based on multiple technologies such as online platforms, Smartphone/Mobile technologies, Supply chain and logistics and Digital Marketing. Online draws support on technologies such as electronic funds transfer, electronic data interchange (EDI), Warehouse Management Systems and E Banking. World Wide Web is the most common used platform for Ecommerce, but with the development of various tablet and smart phone based application, the E Commerce industry is going through big shift. The opportunity opened for countries irrespective of its economic development because of Electronic commerce is immense, E-Commerce virtually eliminated the drawback of distance between buyer and seller as it gives a platform for both of them to interact, communicate and transact in a virtual world (Farida et al., 2017).

Electronic commerce (e-commerce) adalah suatu contoh dari kemajuan teknologi informasi dimana transaksi bisnis tidak lagi dilakukan secara konvensional, yang mengharuskan pembeli berinteraksi langsung dengan penjual atau adanya keharusan menggunakan uang tunai. Tetapi penjual diwakili oleh suatu sistem yang melayani pembeli secara online dengan melalui media jaringan komputer. Dalam melakukan transaksi, seorang pembeli berhadapan dan berkomunikasi dengan sistem yang mewakili penjual. Oleh karena itu, $e$ commerce ini membutuhkan infrastruktur sistem yang mampu menjamin keamanan transaksi tersebut (Lukito, 2017). E-commerce merupakan salah satu mekanisme transaksi yang menggunakan jaringan komunikasi elektronik seperti internet yang digunakan baik oleh negara maju maupun negara berkembang, sehingga aktivitasnya tidak dapat lagi dibatasi dengan 


\section{Jurnal Ilmiah Ekonomi Islam, 6(03), 2020, 669}

batasan geografis dan dapat meningkatkan efisiensi serta kecepatan dalam penyelenggaraan bisnis (Wulandari, 2018).

\subsection{Shopee}

Shopee adalah mobile-platform pencetus utama dan pertama di wilayah Asia Tenggara (Indonesia, Filipina, Malaysia, Singapura, Thailand, Vietnam) dan Taiwan yang menawarkan transaksi bisnis online via ponsel (Fauziah, 2019). Shopee memiliki bermacam pilihan barang, mulai dari elektronik dan aksesorisnya, perlengkapan rumah tangga, produk kesehatan, alat kecantikan, perlengkapan ibu \& bayi, fashion dan style hingga perlengkapan untuk olahraga. Shopee muncul dalam bentuk mobile marketplace sehingga memberi kemudahan penggunanya dalam melakukan kegiatan transaksi online tanpa harus masuk melalui website. Shopee masuk di Indonesia dan resmi diperkenalkan pada Desember 2015 silam. Shopee dinaungi oleh Chris Feng, Shopee memberi kemudahan para penggunanya untuk melakukan jual atau beli barang atau jasa melalui aplikasi yang tersedia di platform $i O S$ dan Android yang dapat didownload melalui playstore. Shopee menyediakan fitur-fitur yang bisa memudahkan melakukan live chat para seller dan pembeli untuk saling berinteraksi dengan cepat dan mudah.

Shopee merupakan (Komara \& Daimah, 2019) salah satu tempat belanja online (e-commerce) terbesar khususnya di Indonesia, di dalam pasar online tersebut terdapat ratusan atau bahkan ribuan transaksi perharinya yang dihasilkan dari pedagang maupun pembeli tanpa bertemu langsung dalam suatu forum tertentu. Dengan melihat kenyataan tersebut, maka tidak bisa dihindari bahwa maraknya bisnis online yang sedang trend dikalangan masyarakat saat ini dapat dijadikan sebagai alternatif untuk melakukan usaha perdagangan yang tidak memerlukan tempat tertentu secara lebih spesifik.

\section{METODE PENELITIAN}

Jenis penelitian ini yaitu penelitian kualitatif. Penelitian kualitatif menurut Lexy J. Moeloeng adalah kegiatan mengeksplorasi dan memahami makna dari sejumlah individu atau kelompok orang yang dianggap memiliki kapasitas dari permasalahan sosial yang akan diteliti. Penelitian ini bersifat diskriptif yaitu upaya untuk menganalisis dan menginterpretasikan data yang telah terkumpul dari proses penelitian kemudian dijabarkan, penelitian ini juga termasuk studi lapangan (field reseach) yang mengacu pada pengamatan dan kumpulan data lapangan sebagai bahan penelitian yang sesuai dengan topik. Pendekatan ini menggunakan teologis normatif, yaitu Pendekatan ini digunakan untuk menganalisis ketentuan-ketentuan hukum yang bersumber pada alQur'an dan hadis terhadap masalah yang berhubungan dengan etika bisnis dan maqshid syariah. Lokasi penelitian Menurut S. Nasution ada tiga unsur pendukung yang sangat penting dalam menentukan lokasi penelitian: yaitu menetapkan lokasi penelitian, tempat, pelaku dan aktivitas ekonomi. Adapun lokasi penelitian ini yaitu di komunitas seller Shopee yang berada di kota Makassar.

\section{HASIL DAN PEMBAHASAN}

\subsection{Penerapan Etika Bisnis}

Etika yang paling pertama dalam Islam adalah niat yang tulus. Dengan niat yang tulus, semua bentuk aktivitas keduniaan seperti bisnis berubah menjadi ibadah. Adapun prinsip-prinsip bisnis Rasulullah adalah: sikap fathanah (professional), amanah (terpercaya), shiddiq (jujur), dan tabligh (transparan). a. Fathanah (Profesional)

Fathanah dapat diartikan cerdas, intelektual, kecerdikan atau kebijaksanaan. Pebisnis yang fathanah adalah pebisnis yang mempunyai kemauan berusaha mencari dan menemukan peluang-peluang bisnis yan baru, prospek dan berwawasan masa depan, namun tidak mengabaikan prinsip kekininian (Zahroh \& Nafik, 2015).

Allah berfirman dalam QS Yusuf/12: 55:

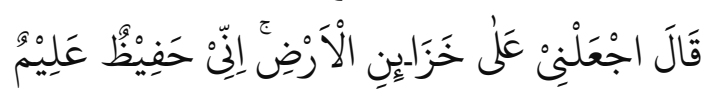

Terjemahnya:

Dia (Yusuf) berkata, "Jadikanlah aku bendaharawan negeri (Mesir); karena sesungguhnya aku adalah orang yang pandai menjaga, dan berpengetahuan."

Mengutamakan Profesionalisme dalam bisnis terutama pada perdagangan elektonik (e-commerce) berupa layanan yang maksimal terhadap pembeli. Merespon pesanan pembeli dengan cepat serta menerima keluhan pembeli dengan penuh keramahan. Pelayanan maksimal terhadap pembeli di era digitalisasi bisnis sangat diperlukan mengingat persaingan semakin ketat, jika layanan terhadap pelanggang tidak direspon dengan cepat dan tepat maka pelanggan akan beralih ke toko online lainnya. Shopee sangan respek dengan pembelinya, respon 


\section{Jurnal Ilmiah Ekonomi Islam, 6(03), 2020, 670}

cepat dan pelayanan maksimal. Jika seller terlambat menaggapi pembeli maka pihak Shopee akan memberikan peringatan kepada pembeli agar dilayani dengan cepat dan baik.

\section{b. Amanah (Terpercaya)}

Sifat amanah (responsibility dan kredibilitas) adalah sifat ini dapat membentuk pribadi yang kredibel dan memiliki sikap penuh tanggung jawab. Sifat amanah memiliki posisi yang penting dalam transaksi bisnis, karena tidak adanya kredibilitas dan tanggung jawab dalam bermuamalah maka kehidupan bisnis menjadi tidak seimbang dan akan kacau (Nafiuddin, 2018).

Allah berfirman dalam QS An-Nisa/4: 58.

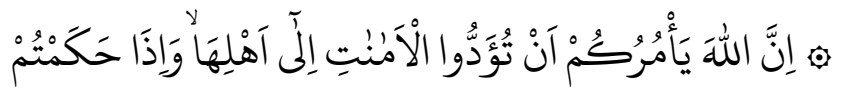

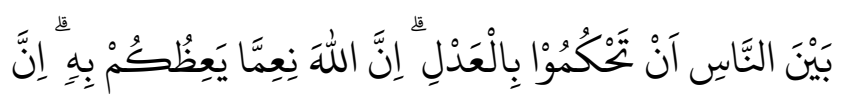

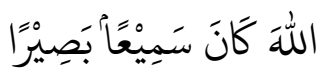

Terjemahnya:

"Sesungguhnya Allah memerintahkan kalian untuk menunaikan amanah-amanah kepada pemiliknya; dan apabila kalian menetapkan hukum di antara manusia hendaklah kalian menetapkan hukum dengan adil."

Dalam konteks transaksi bisnis sikap amanah diimplementasikan oleh seorang penjual dengan menjaga sifat kepercayaan pelanggan. Dalam menjaga hak-hak pelanggan, seller Shopee melaksanakan hal tersebut dengan baik. Barang yang diperjualbelikan oleh seller tidak mengandung unsur membahayakan dan tidak terdapat kecatatan. Jika pembeli menemukan kecatatan pada barang yang dipesan maka barang tersebut boleh direfun atau barang kembali agar pelanggan merasa tidak dirugikan. Kepuasan pelanggan harus diutamakan, jangan sampai keuntungan yang dikejar dengan menghalalkan segala cara tapi kerugian yang didapatkan. Kekecewaan pembeli akan membuat mereka lari dan tidak belanja lagi di Shopee.

c. Shiddiq (Jujur)

Kata shiddiq dalam etika bisnis moderen sering dibahasakan melalui kata integritas. Integritas merupakan salah satu cara bagaimana menjunjung tinggi nilai-nilai dan etika dalam melakukan berbisnis. Pelaku bisnis harus menjadikan integritas ini sebagai sebuah prinsip pokok dalam menjalankan bisnis. Seorang pelaku bisnis harus menjalankan sesuatu dengan kejujuran, kegigihan, keuletan dan mampu bersaing dengan sehat(Nafiuddin, 2018). Tidak berbuat dusta dan selalu berkata jujur merupakan makna dari shiddiq yang harus diterapkan dalam melakukan berbagai macam transaksi bisnis (Zahroh \& Nafik, 2015).

Allah berfirman dalam QS At-Taubah/9: 119.

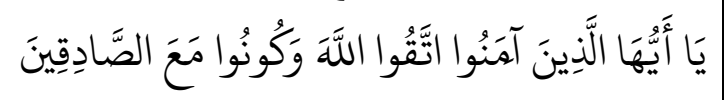

Terjemahnya:

"Wahai orang-orang yang beriman,

bertaqawalah kamu sekalian kepada Allah dan

hendaklah kamu sekalian bersama orang-orang yang jujur".

Perkembangan dunia bisnis yang semakin moderen, kejujuran bisa juga diaplikasikan dalam bentuk kesungguhan kinerja dan ketepatan waktu, baik ketepatan waktu pengiriman, janji, pelayanan yang baik, memperbaiki terus menerus kualitas barang, serta menahan diri dari berbohong dan menipu (baik kepada pembeli maupun ke perusahaan Shopee). Termasuk tidak memberikan infomasi yang penuh kebohongan atas barang yang diperjualbelikan. Shopee dalam hal ini telah belaksanakan sifat kejujuran dengan baik, ketepatan waktu pegiriman, barang tidak cacat, dan pelaporan pengiriman barang bisa dilacak pergerakannya sehingga pembeli tidak was-was dengan barang yang dipesan.

\section{d. Tabligh (Transparan)}

Sifat tabligh dalam bisnis (Nafiuddin, 2018) menurunkan prinsip-prinsip ilmu komunikasi bisnis (personal, interpersonal), seperti penjualan, pemasaran, periklanan, pembentukan opini masa, yang dilakukan dengan benar dan proposional.

Allah berfirman dalam QS Al-Ahzab/33: 70.

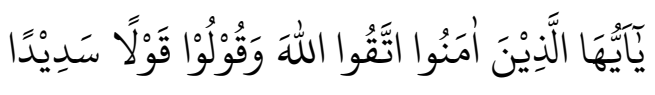

Terjemahnya:

"Hai orang-orang yang beriman,

bertakwalah kamu kepada Allah dan katakanlah perkataan yang benar".

Tabligh dalam konteks transaksi bisnis online diimplementasikan melalui kemampuan seller dalam hal penyampaian kualitas produk beserta spesifikasi secara detail sesuai realistis, hal ini bertujuan untuk menghindari kesan pemberian harapan (php) yang berlebihan tentang kualitas produk yang ditawarkan kepada pembeli. Transparansi tentang barang diperjualbelikan sangat penting karena pembeli tidak melihat langsung barang yang ditawarkan tapi hanya melalui gambar/foto. Transparansi dalam segala hal 


\section{Jurnal Ilmiah Ekonomi Islam, 6(03), 2020, 671}

ini baik spesifikasi barang, kualitas, fungsi, dan kelebihan-kelebihan lainnya dari barang yang ditawarkan. Seller Shopee telah melaksanakan hal tersebut, spesifikasi barang dijelaskan dengan gamblang, sehingga pembeli merasa yakin bahwa barang yang akan dibeli benar-benar sesuai dengan keinginan.

\subsection{Penerapan Etika Bisnis}

\section{a. Hifdz ad-Diin (Menjaga Agama)}

Menegakkan agama merupakan kewajiban setiap muslim tanpa terkecuali, baik dalam ibadah maupun muamalah. Jika kewajiban ini diabaikan, maka eksistensi agama akan terancam. Menegakkan aturan agama demi menjaga kemurnian agama dengan tidak melakukan transaksi yang dilarang dalam agama, seperti melakukan penipuan kepada pembeli, menjual barang yang nyata diharamkan agama dan bentuk muamalah lainnya yang jelas keharamannya dalam syariah Islam.

Seller muslim seharusnya memenuhi kewajibannya untuk menjaga agama, menjalankan etika bisnis islami utamanya dalam bertransaksi, dan menjauhi perbuatan buruk seperti ketidakjujuran, ketidakadilan dan penipuan. Penjual yang menjaga maqashid syariah, lebih bisa menerapkan aturan jual beli yang diatur dalam Islam dengan lebih bisa mengontrol diri agar tidak melakukan perbuatan buruk. Setiap transaksi yang dilakukan selalu bernilai ibadah dan selalu mengharap ridha dari Allah.

Shopee berusaha menjaga hak-hak beragama pelanggan dengan tidak melakukan hal-hal yang melanggar agama saat transaksi. Kepada seluruh seller Shopee mewajibkan untuk menjaga nilai-nilai agama seperti, kejujuran, menjauhi kedzoliman, dan juga menjunjung tinggi akhlak saat transaksi.

b. Hifdz an-Nafs (Menjaga Jiwa)

Menjaga jiwa dalam maqashid syariah diwujudkan dalam bentuk makan dan minum. Apabila hal ini tidak dipenuhi, maka akan merusak jiwa atau kehidupan. Penjual yang lurus akan memenuhi kewajibannya untuk menjaga jiwa dirinya dan pembelinya. Dalam hal ini seller Shopee menjaga jiwa pembeli dengan hanya menjual barang yang halal dan tidak membahayakan kehidupan manusia. Produk yang halal akan berdampak pada mental dan sikap, apabila produk yang dijual berasal dari yang haram, maka pembeli dan penjual tidak akan ragu untuk melanggar aturan-aturan Islam. Penjual yang tidak bermental religius pasti akan berfikir meraup keuntungan besar tanpa memperhatikan aturan syariah.

Menjaga jiwa baik seller Shopee maupun pembeli dilakukan dengan diterapkannya aturan tidak menjual barang yang membahayakan hidup pelanggan, larangan menjual benda tajam, senjata api, dan benda-benda berbahaya lainnya yang mengancam hidup manusia. Aturan tersebut sangat jelas di platform Shopee, jika ada seller yang melanggar aturan tersebut maka dikenakan sanksi berupa penonaktifan toko online.

c. Hifdz al-Aqal (Menjaga Akal)

Allah Swt melarang segala sesuatu yang dapat menyebabkan kerusakan akal atau menghilangkan akal sehat. Agama menetapkan syariah agar memelihara akal dan menganjurkan untuk memanfaatkan akal dengan baik dan cara benar. Adapun hal yang perlu dilakukan orang Islam dalam menjaga akalnya adalah tidak minum alkohol dan segala macam barang yang memabukkan.

Seller Shopee sudah memenuhi kewajiban untuk menjaga akal pembeli. Adanya larangan menjual minuman keras, dan segala sesuatu yang memabukkan adalah bukti bahwa Shopee sinergi dengan maqashid syariah. Seller pun sadar sejak awal dan mengetahui serta memahami lewat edukasi dari pihak Shopee bahwa mengkonsumsi dan menjual minuman keras merupakan hal yang dilarang agama. Larangan mengkonsumsi minuman memabukkan tersebut karena orang yang meminum tidak akan bisa berfikir secara rasional dan sehat, yang akan berakibat mudahnya melanggar aturan-aturan Islam. Tidak hanya minuman, tapi semua jenis memabukkan lainnya seperti heroin, sabu-sabu, dan narkoba adalah barang haram yang tidak diprbolehkan menjualnya di Shopee.

d. Hifdz an-Nasal (Menjaga Keturunan)

Agama mengatur interkasi pergaulan antar sesama manusia, batasan-batasan interaksi antara lakilaki dan perempuan diatur secara jelas dalam nas. Demikian juga aspek pemeliharaan keturunan telah diatur dalam agama dengan rinci. Larangan bagi seller Shopee menjual barang yang mendekatkan ke perbuatan zina baik bentuk gambar, video, kaset CD, DVD, buku-buku porno dan bentuk lainnya. Sebagai seller Shopee, harus bisa memahami dan mengaplikasikan tujuan dari maqashid syariah agar mampu mengontrol diri dari perbuatan yang dapat merusak kehormatan seorang muslim. Tidak hanya untuk seller tapi pemahaman tersebut juga harus 
disampaikan kepada pembeli Shopee. Aturan ketat mengenai larangan menjual barang-barang yang mengundang unsur-unsur seks dan menjurus ke perbuatan asusila telah diatur dalam platform Shopee dengan sangat jelas, jadi seller pun telah mengikuti aturan tersebut dalam transaksi.

e. Hifdz al-Maal (Menjaga Harta)

Agama Islam sebagai agama yang komprehensip telah mengatur pemeluknya untuk memperoleh harta kekayaan dengan cara yang halal. Penjagaan terhadap harta diperlukan keyakinan kuat dan pengaplikasian aturan-aturan transaksi yang sudah dijelaskan dalam al-Qur'an dan hadis serta ijtihad ulama dalam maqashid syariah. Hal ini dapat aplikasikan dengan tidak menjual hal-hal terlarang, baik zat barang maupun cara memperdagangkannya yang secara jelas dilarang dalam syariat Islam. Shopee melarang seller menjual barang yang haram agar seller tidak makan dari hasil haram, misalnya barang hasil curian. Demikian juga seller dilarang menjual barang yang tidak memiliki manfaat terhadap kebutuhan hidup pembeli agar uang tidak habis untuk hal-hal yang tidak dibutuhkan. Seller Shopee juga mengaplikasikan hifdz maal/menjaga harta pelanggan dengan adanya pengembalian barang jika terdapat kecacatan dan kerusakan barang agar pembeli tidak dirugikan karena barang pesanan tidak bisa digunakan.

\subsection{Etika Bisnis E-Commerce Shopee Berdasarkan Maqashid syariah Dalam Mewujudkan Keberlangsungan Bisnis}

Etika bisnis yang didasarkan maqashid syariah mengatur keterpaduan antara antara seller dan pembeli, antara urusan dunia dan akhirat, dan antara kemacetan dan keberlangsungan bisnis. Jika bisnis diatur dengan nilai-nilai kebenaran maka akan mendatangkan keuntungan timbal balik antara entitas bisnis, seller, dan pembeli. Sebaliknya jika dikelola tanpa didasari suatu aturan yang jelas maka bisnis tidak berkembang dan akan mati. Kepercayaan pelanggan sangat dibutuhkan, agar loyalitas tumbuh karena saling mengikat. Shopee sebagai e-commerce terus meningkatkan kepercayaan pembeli dengan memberlakukan aturan ketat bagi seller yang menjual di Shopee. Aturan-aturan yang wajib dilaksanakan oleh seller membuat pelanggan semakin percaya dan yakin bahwa Shopee tempat yang aman belanja online.

Terlaksananya etika bisnis yang sesuai dengan maqashid syariah membawa implikasi yang baik terhadap keberlangsungan bisnis Shopee, pembeli yang semakin meningkat kepercayaan terhadap shopee sehingga mereka loyal untuk terus belanja di Shopee. Demikian juga seller semakin setia menjual di Shopee karena jumlah pembeli semakin bertambah yang berpengaruh terhadap keuntungan yang semakin meningkat pula. Keberlanjutan bisnis merupakan tujuan utama bisnis itu sendiri. Sebagai e-commerce yang mulai popular dan disenangi pembeli, Shopee semakin meningkatkan kualitas layanan dengan menekankan menjaga kepercayaan pada seller. Menjaga sikap professional, kepercayaan, kejujuran serta transparansi penting dijaga agar pembeli semakin konsisten belanja di Shopee. Selain itu menjaga lima hal pokok kepada seluruh seller seperti menjual dengan memperhatikan norma agama, tidak menjual barang yang dapat mengancam hidup manusia, tidak menjual barang memabukkan, tidak menjual barang yang menjurus pada prostitusi, dan memperoleh harta dengan cara halal merupakan sesuatu yang penting untuk diperhatikan oleh seluruh seller agar bisnis terus berlanjut.

\section{KESIMPULAN}

Empat sifat etika bisnis yang telah diterapkan oleh Muhammad Saw, tersebut telah diterapkan pada e-commerce seller Shopee. Fathanah (profesional) diterapkan berupa layanan yang maksimal terhadap pembeli. Merespon pesanan pembeli dengan cepat serta menerima keluhan pembeli dengan penuh keramahan. Selanjutnya amanah, diterapkan dengan menjaga hak-hak pelanggan. Sikap shiddiq, Seller Shopee telah belaksanakan sifat kejujuran dengan baik. Sikap tabligh, Seller Shopee telah melaksanakan hal tersebut, spesifikasi barang dijelaskan dengan gambling.

Pada penerapan maqashid syariah, Pertama, menjaga agama, Shopee berusaha menjaga agama pelanggan dengan tidak melakukan hal-hal yang melanggar agama. Kedua, menjaga jiwa baik seller maupun pembeli dilakukan dengan diterapkannya aturan tidak menjual barang yang membahayakan hidup pelanggan. Ketiga, menjaga akal, Shopee sudah memenuhi kewajiban untuk menjaga akal pembeli. Adanya larangan menjual minuman keras, dan segala sesuatu yang memabukkan. Keempat, menjaga keturunan, Shopee telah mengeluarkan aturan ketat mengenai larangan menjual barang-barang yang mengundang seks dan menjurus ke perbuatan asusila. Kelima, menjaga harta, Shopee melarang seller 
menjual barang yang tidak bermanfaat dan pengembalian barang jika terdapat kecacatan.

Terlaksananya etika bisnis yang sesuai dengan maqashid syariah membawa implikasi yang baik terhadap keberlangsungan bisnis Shopee, pembeli yang semakin meningkat kepercayaan terhadap shopee sehingga mereka loyal untuk terus belanja di Shopee. Demikian juga seller semakin setia menjual di Shopee karena jumlah pembeli semakin bertambah yang berpengaruh terhadap keuntungan.

\section{UCAPAN TERIMA KASIH}

Pada kesempatan ini, ijinkan peneliti menyampaikan rasa syukur yang tak terhingga kepada Allah SWT atas segala limpahan karuniaNya. Terimakasih kepada keluarga peneliti yang selalu memberikan dukungan tak kenal lelah dalam situasi dan kondisi apapun. Ucapan terimaksih kepada dosen promotor dank o-promotor atas bimbingannya sehingga penelitian ini dapat selesai, tak lupa ucapan terimaksih juga kepada teman-teman seller Shopee Makassar atas bantunnya dalam penelitian ini. Terakhir ucapan terimakasih kepada pascasarjana UIN Alauddin Makassar atas kesempatan yang diberikan dengan diterbitkannya penelitian ini, semoga dapat menambah khasanah keilmuan bagi dunia pendidikan Indonesia. Serta berbagai pihak yang telah memberikan inspirasi dan dorongan semangat, yang tak bisa disebutkan satu persatu tanpa mengurangi rasa hormat peneliti, semoga Allah SWT membalas dengan yang jauh lebih baik, aamiin.

\section{REFERENCES}

Anindya, D. A. (2017). Pengaruh Etika Bisnis Islam Terhadap Keuntungan Usaha Pada Wirausaha Di Desa Delituakecamatan Delitua. At-Tawassuth, 2(2).

Aziz, A. (2013). Etika Bisnis Perspektif Islam: Implementasi Etika Islami Untuk Dunia Usaha. https://www.academia.edu

Chasanah, N., Luhita, T., \& Fandestika, S. R. (2018). Implementasi E-Service Quality Pada ECommerce Komunitas Muslimah Entrepreneur. 14(1), 29-38.

Dewantara, A. W. (2017). Filsafat moral, Pergumulan Etis Keseharian Manusia.

Dewi Irmawati. (2011). Pemanfaatan E-Commerce Dalam Dunia Bisnis. Jurnal Ilmiah Orasi Bisnis - ISSN: 2085-1375, Edisi Ke-V(November), 95112.
Djakfar, M. (2007). Religion, Work Ethics, and Business Attitude: A Case Study on the Meaning of Business Behavior of Madurese Fruits Traders in Malang. Center for Indonesian Acconting and Management Research, 16(2), 18.

Farida, N., Naryoso, A., \& Yuniawan, A. (2017). Model of Relationship Marketing and ECommerce in Improving Marketing Performance of Batik SMEs. JDM, 8(1), 20-29.

Fauzi, Y. (2015). Manajemen Pemasaran Perspektif Maqasid Syariah. Jurnal Ilmiah Ekonomi Islam, 1(03). https://doi.org/10.29040/jiei.v1i03.51

Fauziah, I. S. (2019). Perilaku Konsumen Dalam MarketPlace (Studi Kasus di Shopee dan Tokopedia Perspektif Etika Bisnis Islam).

Hadi, K. (2012). Implementasi Maqoshid Syariah Sebagai Indikator Perusahaan Islami. 1(3), 140150.

Juliyani, E. (2016). Etika Bisnis dalam Perspektif Islam. Jurnal Ummul Qura, 7(1), 63-74. https://doi.org/10.36835/iqtishodiyah.v4i1.74

Komara, S., \& Daimah. (2019). Analisis Transaksi Jual Beli Pada Marketplace Shopee Dalam Persfektif Ekonomi Syariah. Syntax Idea, 1(3), 81-100. https://doi.org/.1037//00332909.I26.1.78

Lukito, I. (2017). Tantangan Hukum dan Peran Pemerintah dalam Pembangunan E-Commerce (Legal Challenges and Government'S Role in ECommerce Development). JIKH, 11(3), 349367.

Meidita, Y., Suprapto, \& Rokhmawati, R. I. (2018). Pengaruh Kualitas Layanan Terhadap Kepuasan , Kepercayaan dan Loyalitas Pelanggan pada ECommerce ( Studi Kasus: Shopee ). JPTIIK, 2(11), 5682-5690.

Misbahuddin. (2012). E-Commerce dan Hukum Islam. Nafiuddin. (2018). Memahami Sifat Shiddiq Nabi Muhammad SAW Perspektif Bisnis Syariah. BISNIS, 6(1), 116-126. https://doi.org/10.29333/aje.2019.423a

Nawatmi, S. (2010). ETIKA BISNIS DALAM PERSPEKTIF ISLAM Sri Nawatmi. Fokus Ekonomi (FE), 9(1), 50-58.

Putra, P. (2015). Implementasi Maqashid Al-Syari , Ah Terhadap Pelaksanaan Csr Implementasi Maqashid Al- Syari' Ah Terhadap Pelaksanaan Csr Bank Islam : Studi Kasus Pada Pt . Bank Bri Syariah.

SHARE,

$4(1)$ https://doi.org/10.22373/share.v4i1.724 
Jurnal Ilmiah Ekonomi Islam, 6(03), 2020, 674

Saifullah, M. (2011). Etika Bisnis Islami Dalam Praktek Bisnis Rasulullah. Walisongo: Jurnal Penelitian Sosial Keagamaan, 19(1), 127. https://doi.org/10.21580/ws.19.1.215

Sampurno, W. M. (2016). Implementation of Islamic Business Ethics and Its Impacts on Family Business. Journal of Islamic Economics Lariba, 2(1), 25-30. https://journal.uii.ac.id/JIELariba/article/view/96 $71 / 7857$

Soediro, A., \& Meutia, I. (2018). Maqasid Sharia As a Performance Framework for Islamic Financial. Multiparadigma, $\quad 9(1), \quad 70-86$. http://repository.uinsu.ac.id/5517/1/FIQH MUAMALAH KONTEMPORER.pdf

Sudiarti, S. (2018). Fiqih Muamalah Kontemporer. http://repository.uinsu.ac.id/5517/1/FIQH MUAMALAH KONTEMPORER.pdf

Tiakoly, K., Wahab, A., \& Syahruddin. (2019). Penerapan Etika Bisnis Islam Pada Usaha Pedagang Barang Campuran di Pasar Tradisional Gamalama. Iqtisaduna, 5(1), 102-123.
Wulandari, D. N. (2018). Etika Bisnis E-Commerce Berdasarkan Maqashid Syariah Pada Marketplace Bukalapak.Com. JMM UNRAM MASTER OF MANAGEMENT JOURNAL, 6(1). https://doi.org/10.29303/jmm.v6i1.21

Wulandari, D. N., Santoso, B., \& Athar, H. S. (2018). Etika Bisnis E-Commerce Berdasarkan Maqashid Syariah Pada Marketplace Bukalapak.Com. Jmm Unram - Master of Management Journal, 6(1). https://doi.org/10.29303/jmm.v6i1.21

Yulistia, Y. (2017). Analisis Pengaruh Efektivitas Dan Manfaat E-Commerce Terhadap Sikap Dan Perilaku Pengguna Dengan Menggunakan Metode TAM (Studi Kasus: UKM Kota Palembang). JATISI (Jurnal Teknik Informatika Dan Sistem Informasi), 4(1), 93-100. https://doi.org/10.35957/jatisi.v4i1.91

Zahroh, F., \& Nafik, M. (2015). Nilai Fathonah Dalam Pengelolaan Bisnis Di Pesantren Mukmin Mandiri Sidoarjo. 2(9), 745-758. 